\title{
Ethics, Law and Justice in Achebe's Things Fall Apart
}

\author{
Ogbujah, Columbus \\ Institute of Foundation Studies, Rivers State University of Science \& Tech., Port Harcourt, Nigeria.
}

\begin{abstract}
All human societies, except perhaps, the Hobbesian state of nature, are preserved through a complex network of laws, ethics and the enforcement of justice. Whether couched in unwritten customs and traditions by which primeval peoples organized their lives, or in standardized penal codes of 'civilized' cultures, laws and their enforcement are expedient for meaningful interrelationships, social order, peaceful co-existence and economic growth of any society. By sifting out the distinctive imports of ethics, law and justice system in the ordering of pre-colonial Igbo (African) society, exemplified in the life of Umuofia, the author sought to illumine the readerson the wits of Achebe's Things Fall Apart in presenting a well-ordered society, as against Western criticisms. Specific events / cases which projected these vital societal structures were identified. Instances where the colonial system of adjudication conflicted with that of the natives were rife.A suggestion that like communities of other climes, their ethical, legal and justice systems were open to evolution was highlighted. Findings revealed that even though Achebe did not engage himself directly in the polemics of the derivable value of the white man's action in Umuofia, his disclosures underscored the genesis of bribery and corruptiona twin monster which have blossomed in people's psyche today.
\end{abstract}

Keywords: Customs, Ethics, Justice System, Law,Peaceful co-existence.

\section{Introduction}

In all ages and cultures, human beings have exhibited certain defining qualities. Whether at the rudimentary stage of social interactions characteristic of primeval cultures, or at the highly sophisticated level of social engineering of modern life, human societies have always been preserved through a complex network of laws, ethics and the enforcement of justice. Except, perhaps in the Hobbesian state of nature (where the only operating rule is that of survival of the fittest) every human society, functioning within the confines of social contract, has its own system of values which gives rise to norms that are responsible for the day-to-day ordering of the society. For harmonious living, the values and norms therefrom, must be respected, and a system of redress/punishment put in place to discourage dissent.

Achebe's literary genius lies not only in his originality, but also in his ability to couch everyday lives in simple prose that significantly contrast the socio-political ordering of traditional African communities with those of the West. An in-depth analysis of his Opus magnum - Things Fall Apart reveals that at the heart of the narrative of a people's worldview which E. B. Tylor [1920 (1871)]pejoratively termed 'primitive', lie a revered ethical system, a 'transforming' judicial process and a robust check and balance structure as ballasts to human excesses. In the following paragraphs, we shall attempt to situate the actions of the principal characters in Things Fall Apart within the general framework of ethics, law and justice which Africans were known for, even before the advent of colonialism.

\section{Ethics, Meaning of}

As a noun, the term Ethics is generally used in two senses: a) as motivation based on ideas of right and wrong; and b) as the philosophical study of moral values and rules. The former deals with values (which are right or wrong) as they guide people's actions; the later deals with the analysis of the rightness or wrongness of human actions. While it is impossible to totally divest one from the other, we shall attempt to devote our attention to the former sense since it forcefully captures the context under which the term is used here. Consequently, ethics is defined as 'the rules of conduct recognized in respect to a particular class of human actions or a particular group, culture, etc' (Dictionary.com).

Understood from its etymological roots - ethikos (customary) and its cognate concept ethos (customary behaviour), the term is used to denote the way humans act and conduct themselves. It could be personal, asin self-imposed standards within which the individual chooses to work; orsocial / public, as in norms of a society or a code of professional standards containing aspects of fairness and duty to the general public and the profession (Ogbujah, 2011). As such, ethics as expressed in 'Definition of Anthropological terms', is understood to bethe principles of conduct governing an individual or group of individuals, concerning what is right or wrong, good or bad (online).Since humans are ineluctably tied to the community, social ethics then 
deals with the principles which make human conducts acceptable or unacceptable, good or bad within the social group.

In life, people have always pursued different kinds of goals - their personal health, wealth, pleasure, efficiency and over-all wellbeing, on one hand, and that of the general good or social group, on the other hand. In pursuance of these personalized incompatible interests and goals, individuals constantly crossed each other's parts, leading to conflicts and sometimes anarchy within the social group. In consequence, there arose the need for a standard to regulate people's behaviour; a code of conduct that would enable individuals lawfully (at least within limits) direct their lives toward these varied ends without let or hindrance; a process that would make it easy to vindicate between rights and wrongs in human actions.

\section{The Notions of Law and Justice}

The term Law is a common but complex concept capable of signifying multiple phenomena. It is common because it is a house-hold term in every culture, organization and institution, and people generally seem to understand what it represents; on the other hand, its complexity lies in the fact that by nuanced step, it could be used to represent distinct layers and/or categories of realities thereby creating room for prevarication typical of ambiguous concepts. Perhaps this was why McCoubrey and White (1996) insisted that the question: 'what is law?' has no simple answer. And so it is expedient to provide a précising definition of law in order to streamline the limits of its applicability within the context of our discussion.

According to Oxford Dictionaries (online), law is construed to mean 'the system of rules which a particular country or community recognizes as regulating the actions of its members and which it may enforce by the imposition of penalties'. This designation is very instructivesince it is believed that for anything whatsoever to qualify as law, it must incorporate some or all of theseor their variants, namely:a) a system of rules; b) accepted by a recognizable specific group of people for regulating their lives; and c) enforceable through the imposition of penalties. Thus, whether seen as an 'interpretive concept' to achieve justice (Dworkin, 1986), or as an 'authority' to mediate people's interests (Raz, 2009), or simply as a 'system of rules' (Campbell, 1995), the overall motif of legal experts when delineating law entails, even if tacitly, these outlined trio. Evenwhen Aquinas(1954) insiststhat 'law is a rational ordering of things which concern the common good that is promulgated by whoever is charged with the care of the community', his contention is somewhat aconfirmation of these principal qualities by charting the source of force of the rules that govern people's lives viz., a competent authority. That is, for any rule to have the force of law, it must be given by those who have been charged by the common will to do so.

However, among positivists,Bentham's (1789) efforts are interpreted as grounding the authority of the Law on the principle of maximizing the 'Happiness of the greatest numbers'. So, whether the emphasis is on the acceptability of the law, or on the authority of its maker(s), or on its utility, every law which is enforceable through human sanctions is made by man, to be obeyed by all and for the wellbeing of everyone. Rousseau (1762) noted:

But what, after all, is a law? [...] When I say that the object of laws is always general, I mean that law considers subjects en masse and actions in the abstract, and never a particular person or action. [...] On this view, we at once see that it can no longer be asked whose business it is to make laws, since they are acts of the general will; nor whether the prince is above the law, since he is a member of the State; nor whether the law can be unjust, since no one is unjust to himself; nor how we can be both free and subject to the laws, since they are but registers of our wills. [...]Laws are, properly speaking, only the conditions of civil association. The people, being subject to the laws, ought to be their author: the conditions of the society ought to be regulated solely by those who come together to form it.

Laws are thus just rules of conductfreely made by man for the guidance of everyone's life, contrived out of human need for justice and order in societies and organizations.

As originating from the will of the people either directly or indirectly (as in the case of representative legislative bodies), laws are indispensable for smooth ordering of societies and institutions. A society without laws, and perhaps also, an effective means of enforcing the laws, would be like the animal kingdom where 'might is right', and only the fittest of animals survived; it would be a chaotic, dysfunctionalstate reminiscent of Hobbesian 'state of nature' where live was 'solitary, poor, nasty, brutish and short' (Hobbes,2010 [1651]). This may seem an extreme position given as some would argue that there are people who are not selfish, and as such, would still live happily with others without laws. This objection in itself is an awfully rare situation particularly in a world of scarce resources, and especially if one wasfaced with the challenge of finding bare necessities for survival. It could actually be cogent to kill someone before he kills you, that is, if you want to carry on living, 
as Hobbes would say. This was perhaps, why the Sargent of Arms at the Canadian parliamentwas highly applauded for shootingMichael Zehaf-Bibeau before he could kill more people at the Ottawa parliamentary chambers, Canada, on the $22^{\text {nd }}$ of October 2014. Thus, in reality, it is only the rule of law and the threat of punishment that keep humans in check.

Justice, on the other hand, is a notion with varying layers of understanding among peoples of diverse cultures. Even though there may be certain justice principles that cut across cultures, every culture, being unique, creates specific ethical values which in turn, influence the people's perception of the meaning of justice. In the ancient Greece where slave-holding was an accepted practice, for instance, Aristotle would see justice not in terms of equality but right proportion. Since a slave was a property, and there could be no injustice to one's property, it was preposterous to expect a 'master' and his 'slave' treated equally by law (Nicomachean Ethics. Bk.V, CH.6, 1134b). This perhaps, explains why in prescribing treatment for slaves and freedmen, Plato, in The Laws(1970:451-2) uses Socrates to state that 'anyone who wishes - provided he is in his right mind - may seize his own slave, and (within the permitted limits) treat him as he likes'. Plato went further to justify the condition of slaves and thus acquiesce with the slave-hunter's self-absolution from wrongdoing by averring that if a man secured the release of a slave, except by furnishing three credit-worthy sureties, he was liable to a charge of violence.In this vein, the manumittor (slave owner) who inflicts violence on his captive by virtue of denial of his fundamental rightsshould have no qualms of conscience, but the one who secures the releaseof the latter must be prosecuted. What a conundrum?

In his dialogue Republic(1955), Plato seems to shift from this hard-line stance in his treatment of slaves, and becomes more critical of actions of people that claim to be just. Within the conversations,Simonidesis credited to have insinuated that 'justice is giving every man his due' (Bk. I, 331e), which implies benefiting one's friends and harming one's enemies. Thrasymachusclaims that it is 'what is in the interest of the stronger party' (Bk. I, 338c).Plato, using the character of Socrates,painstakingly counters thesepositions by arguing that it is never right for a just man to harm anyone at any time.A just ruler would act not just in his interest, but in the interest of the people he rules.For him, justice is havingand doing one's own job; it is harmony. A just man is a man in just the right place, doing his best and giving the precise equivalent of what he has received (Bk. IV, 434a).

In the modern times, John Rawls' work is acclaimed as having made significant inroads into the notion of justice. In his influential book: A Theory of Justice, Rawls (1999:3) claims that "Justice is the first virtue of social institutions, as truth is of systems of thought". It affords individuals and groups fair treatment and impartial share of the goods of society. For him, everyone possesses a certain kind of inviolability grounded on justice which even the welfare of society in general cannot supersede. In consequence, the principles of justice cannot trade-in the loss of freedom of some people even for a greater good shared by others. Rawls' emphasis was on how societies should be organized to benefit all in what is termed 'distributive justice'. This seems to agree with the claims of those who believe justice is part of natural law that entails 'according individuals or groups what they actually deserve, merit, or are entitled to'. It is a notion involving the fair, moral and impartial treatment of all persons, especially in law.

In the past two hundred years, experts have extensively expounded the notion of justice, shedding much light in some grey areas that were side-stepped by ancient philosophy. Aside from 'Distributive justice' which envisions justice as possible onlywithin the coordinates of equality and fairness; we have the 'Retributive justice' which is concerned with punishment for wrongdoing; and also the 'Restorative justice' (equally called 'reparative justice') that focuses on the needs of victims and offenders, instead of satisfying abstract legal principles or punishing the offender. In general, the laws of every society do specify the procedures for redress, and the range of penalties that maybe imposed by constituted authorities for various offenses. Infringement of the provisions of the laws and customs of the land almost always attracts penalties. The most commonly acclaimed reasons for imposing penalties include:

Retribution -Punishment imposed as a response that satisfies the aggrieved party, their loved ones, and society.

Deterrence-To the individual (through fear of further punishment), and to the generalpublic (potential offenders warned as to likely consequence of offense).

Rehabilitation - To reform the offender's behaviour

Incapacitation - Offender is made incapable of committing further crime to protect the general society from crime.

Reparation - Repayment to victim(s) or to community 
Denunciation-Society expressing its disapproval to crimes, reinforcing moral boundaries.

With these, the notions of law and justice are not to be construed as utopic concepts with improbable factual implications, but practical realities experienced in the social interactions of people living within specific societies.

\section{The Diffusion of Ethics, Law and Justice in Things Fall Apart.}

The literary genius of Achebe's Things Fall Apart(1958) lies not only in the transformation of conventional wisdom into a philosophical masterpiece, but on his subtle and meticulous showcasing of a people with a rich cultural heritage. He was unfazed by Tylor's depiction of Africans as 'primitive', but set out through literary artistry, to espouse the wisdom and efficacy of the ethical, legal and justice systems that were operative among indigenous peoplesbefore the advent of imperialism.

As pertaining to rules governing human conduct within specific group or culture, ethics is found in Achebe's various plots and narratives. Of course, without ethics, it is not possible for people to live as a community. This is all the more significant because for laws to even exist there must be an ethical base to lay them on. The first indication of this in Achebe's Things Fall Apart is thehigh sense of respect for authorities and the elders. Everyone who wanted to progress in life never lost sight of this ethical sense.As Ogbujah (2014) noted, an elder was respected not only because he was an embodiment of wisdom due to his vast experiences, but because his white hairs depicted his closeness with the ancestors - the custodians of the land. Thismoral sense was epitomized in the life of Achebe's principal character - Okonkwowho capped his deeds with this unmistakable apothegm: "a man who pays respect to the great paves the way for his own greatness" (14).

Even though polygamy had the tendency to create a 'house of commotion', Achebe depicted harmonious family scenarios where multiplicity of persons became a formidable source of strength and family economic productivity rather than diminution, with each taking their proper positions. When, for instance, Okonkwo came to the rich elder - Nwakibie with some wine to solicit for yam seedlings, the beverage was shared following a prescribed order: beginning from the eldest mento the youngest, and down to the women. But because Anasi - Nwakibie'sfirst wife was not there, the other four wives stood waiting, for they 'could not drink before her' (14). Eventually, after she drank, 'the other wives drank in the same way, in their proper order' (15):a procedure depicting a high level of respect for family values for hierarchical order.

Furthermore, adherence to communal ethical values was also prominent both in gender differentiation in occupations (16), and in the cleansing of polluted land (87). With regard to the former, it sounds curious that even thoughOkonkwo desperately needed more hands to help cultivate yams in order to build up his barn, he could not implore the services of his family. He literally ground his way through to greatness in strict obedience to his culture's ethical ideals pertaining to gender differentiation in crop growing. His father, Unoka - a lazy worthless drunk, could not help matters. Although his mother and sisters worked hard enough, they could only grow women's crops, like coco-yams, beans and cassava. 'Yam, the king of crops, was a man's crop' (16), and any woman who dared cultivate it ran the risk of being severely punished. As a result, Okonkwo suffered alone in his struggles to build a rich barn of his own.

Life, in Achebe's literary setting, was always organized according to prescribed norms. The general African sense of sacredness of life pervaded the atmosphere, and anything that led to life's destruction was treated with utmost disdain. 'It was a crime to kill a clansman, and a man who committed it must flee from the land' (87). For inadvertently killing the sixteen year old son of Ezeudu at the latter's funeral, Okonkwo was forced to flee from the land for seven years; his livestock and barns destroyed, and his houses razed down. Even his best friend - Obierika, joined in the exaction of vengeance in order to cleanse the land because whether deliberate or accidental, shedding of innocent blood polluted the land. And if the clan did not exact punishment, the wrath of the earth goddess would be let loosed on all.In consequence, people were effectively deterred from acts that could lead to the murder of their kinsman.

But this sort of ethical sense is, in itself, fraught with ambivalence, since it did not proscribe all forms of killing: a man was permitted to'justifiably' kill a stranger. This was why the people of Abame did not have qualms in killing the white man who they could not understand his mission in their land. And also whyit was Okonkwo's duty to kill the innocent boy Ikemefuna, but was cursed when he accidentally killed one of his own tribesmen. The sense of the sacredness of life therefore, was binding only when it concerned people from one's immediate in-group. This skewed practice made no sense toOkonkwo's son -Nwoye, and a few others who eventually became the first converts to Christianity.

In spite of dearth of written materials and print technology, Achebe presents the people as conscious of an overtly codified system of rules which was enforced through the imposition of penalties. There were laws regulating virtually all departments of people's lives: conducts during the Week of Peace (21); prohibitions on Ozo title holders (48); concerning marriage (chs. 8 \& 12); divorce (64); burials (47 \& 86); straying cows (80), etc. From chapter four, Achebe, in his ingenious manner began to lay down the rules by means of showcasing the lot of offenders. The Week of Peace, for instance, was a sacred week in which a man did not say a harsh 
word to his neighbour in Umuofia.It was to be observed a week before planting season in honour of the earth goddess without whose blessing their crops would not grow. During the period, no work was done, people moved around making merriments, and were barred from causing harm even in the face of ominous provocations. Achebe accentuated this by the use of somewhat exaggerated metaphor when the character, Ezeani -the priest of the earth goddess challengedOkonkwo thus: "Your wife was at fault, but even if you came into your obi and found her lover on top of her, you would still have committed a great evil to beat her" (22). This was why even though Okonkwo was provoked to justifiable anger by his youngest wife - Ojiugo, he still should not have laid his hands on her.Consequently, for beating his wife (for her gross negligence) in the Week of Peace, which ordinarily would have been ignored if it happened at other time, Okonkwo incurred the wrath of Ezeani and was forced to pay heavy fines to appease the land.

Achebe mirrored acommunity at which everyone was free to conduct their businesses within the confines of the law. Since most of the laws were believed to have spiritual undertones, connecting the living with the dead, and sanctioned by the authority of the gods, it was imperative on the part of the administrators to ensure their strict compliance. When, for instance, Ezelagbo's husband's cow was let loosed on their neighbour's crops, the cow was immediately driven back, and the owner was made to pay a heavy fine imposed by the village (80); and when Ezeudu the great warrior died, because he had taken three titles, the law stipulated he had 'to be buried after dark with only a glowing brand to light the sacred ceremony' (86). Achebe's depiction of the sanctity of laws within the Umuofia community was epitomized in the life of Okonkwo. Having taken the Ozo title, he was prohibited from climbing to tap palm wine, even though he could tap the short ones standing on the ground. So, he had to painfully lease that job to younger and often inexperienced men who ended up 'killing palm trees in the name of tapping'.Confronted by his good friend - Obierika about the incredulity of such a law, he rebuffed the idea with a quixotic expression: "But the law of the land must be obeyed" (48).

Furthermore, there is a suggestionas to the evolutionary trend of laws in Umuofia, much like in any of the so-called 'civilized' societies. As societies develop from the more 'primitive' to a more 'refined' nature, they do so with norms and ethical values commensurate with their level of evolution. This was the case with Achebe's Umuofia community. When Okonkwo paid the fineof 'one she-goat, one hen, a length of cloth and a hundred cowries' for breaking the sacred 'Week of Peace', the oldest man in the village - OgbuefiEzeudu noted that the punishment for breaking the Peace of the land had become very mild in their time. He narrated how his father was informed that in the past, a man who broke the peace was dragged on the ground through the village until he died. But with time, and properunderstanding that causing someone's death spoilt the peace which it was meant to preserve, they elders stopped the practice (22-23). Thus, the mere passage of time, coupled with better enlightenment conditioned the evolution of law and punishmentin Achebe'sThings Fall Apart.

Added to ethics and law is the reality of justice which interspersed the whole spectrum of Igbo life and culture, ranging from distributive justice (13-14), to retributive justice $(9 ; 64-66 ; 86 ; 125)$, and even to a form of 'jungle justice' (97-98). When,for instance, Unoka consulted Agbalato profess his innocence and demand why he was continuallybedeviled with poor harvest, the priestess simply told him that he could not harvest more than he had laboured for:

You have offended neither the gods nor your fathers. And when a man is at peace with his gods and his ancestors, his harvest will be good or bad according to the strength of his arm. You, Unoka, are known in all the clan for the weakness of your matchet and your hoe. When your neighbours go out with their axe to cut down virgin forests, you sow your yams on exhausted farms that take no labour to clear. They cross seven rivers to make their farms; you stay at home and offer sacrifices to a reluctant soil. Go home and work like a man (13).

By this, the Agbala priestess echoed the Igbo belief on natural (distributive) justice which entailed equity, that is, whatever a man sowed, he reaped. Unoka was lazy with his farm work, and his produce was a lousy one. He merely received his due at harvest time. This equity component is forcefully couched inNwakibie's prayer over the kolanut he presented to Okonkwowhen he said: "you will have what is good for you and I will have what is good for me. Let the kite perch and let the eagle perch too. If one says no to the other, let his wing break" (14). Equity or distributive justice demands giving everyone equal opportunity to flourish.

Achebe used the unfortunate incidence of the killing of OgbuefiUdo's wife at Mbaino market to showcase the Igbo judicial process. Enraged by the event,Umuofia sent Okonkwo as an imperious emissary of war to Mbaino, asking them to choose betweenwar, on one hand, or to offer a young man and a virgin as compensation, on the other. The people of Mbaino choose to offer them a lad of fifteen called Ikemefuna, and a young virgin to avert the war. The virgin was given to OgbuefiUdo to replace his murdered wife (8-9). Thus, in 
this 'tribal justice', there were elements of retribution, deterrence, reparation and denunciation, even though it lacked equity because of the non-proportionality of the punishment imposed as a response that satisfied the aggrieved party.

Again, we glean something of retributive justice in the Egwugwu trial for the settlement of the dispute between Uzowulu and his absconded wife's family - Odukwe. Crude as it might seem to modern systems of adjudication, Achebe's Umuofia had a judicial system whereby litigations were brought, disputants' briefs were taken, testimonies of witnesses were received and the judges evaluated the matters before pronouncing judgments. It was more like a jury system constituted of nine Egwugwu who were masked leaders of the nine villages that made up the clan. Their leader - who played the role of the chief judge, was called Evil Forest. After Uzowulu's complaints and Odukwe's response were taken, two other witnesses were brought in to give their testimonies. Eventually, their testimonies corroborated that of Odukwe, affirming the incessant beatings Uzowulumeted out to his wife - Mgbafo, who is of Odukwe's family. The nine egwugwu retreated in consultation for a moment. And when they emerged, the Evil Forest delivered their judgment, ordering Uzowulu to go beg his wife with a pot of wine (64-66). This verdict which compelledUzowulu to humble himself before his wife is construed as a symbolic punishment for the offense,no matter how insignificant it might seem.Thus, although Evil Forest underscored that their duty was not to apportion blame or praise to anyone, his judgment showed an unmistakable denunciation of evil and cowardice: "it is not bravery when a man fights with a woman" (66), he told Uzowulu. In all, the Egwugwu trial showed that among the traditional clans, judgment was based on true evidence, since 'there were no lawyers and there were no liars' (151).

As the drama unfolded, Achebe seemed to contrast this traditional system of adjudication based on true evidence, with the White man's system of justice fraught with corruption. The White men came with their religion, condemning all the customs and religious practices of the natives, and promising to create a better society for them. But in the end, they brought corruption (124; 139), disrespect of the elders (138), stoked conflict among brothers (131), and implanted deceit in their psyche (137). A key index in the imperialist's thirst for revenge and in flagrant disregard for all civilized forms of adjudication was the 'jungle justice' exhibited in the massacre of the people of Abame. Some people of Abame committed a crime by killing a White man who trespassed into their land, and of whom their oracle foretold was a harbinger of doom for their community. And what did the imperialists do? They carried a reconnaissance of the community, waited in ambush for the people to gather en mass at their big Afor market for business transactions, and like modern Islamist fighters, began to shoot everyone in sight. Everybody was killed except the old and the sick that were at home, and a handful of men and women who were lucky not to have arrived before the shooting began (97-98). That was the kind of justice systemthe White men brought to the so-called 'primitive' people.

Again, the land dispute between Aneto and the Nnama's family was another case that highlighted the inept and corrupt nature of the white man's justice system. When Oduche sustained injuries from the fight with Aneto over the land, the white man in charge sent his emissaries to catch and imprison Aneto with all the leaders of his family. In the end, Oduche died and Aneto was taken to Umuru and hanged without any judicial procedure, while all the members of his family were tortured before being released (125). But much more importantly, the white man's court awardedthat piece of land (which everyone knew belonged to Aneto's family)to Nnama's family whose members gave so much money to the white man's messengers and interpreter (124). Thus, with the advent of Europeans in Igbo land, judgment was no longer based on true evidence, but on the financial power and willingness of litigants to purchase it; it was no longer aimed to reconcile warring parties, but to apportion blame and inflict punishment. It was the beginning of the rape of African culture.

A further affront to the sensitivity of a people deeply seeped in a system with high ethicalstandards was the deceitfulnessof the white men exemplified in the character of their District Commissioner. In his absence, one of the overzealous converts - Enoch stoked conflict with the people by desecrating their Egwugwu. Enraged by this heinous action, the people went and burnt the white man's church where Enoch took refuge. When the District Commissioner returned, he invited the elders of the clan for a peace meeting with these words:

'I have asked you to come', began the Commissioner, 'because of what happened during my absence. I have been told a few things but I cannot believe them until I have heard your own side. Let us talk about it like friends and find a way of ensuring that it does not happen again' (137).

These soothing words made the elders lose their guard and settle for a reconciliatory meeting without knowing it was a ploy to disarm and arrest them. Before they could realize it, they were handcuffed and thrown into the guardroom, and were given neither the opportunity to explain what happened nor to defend themselves. In the end, the District Commissioner demanded a fine of two hundred bags of cowries for their release. And as if to finally crush their wounded ego, he went on to admonish them to appreciate the impartial nature of the white man's judicial system. At that time, the questions that could have agitated the minds of these natives, I suppose, 
would have been: what kind of deceitful beings were these whose words did not match their actions? What type of legacy were they trying to create? Of course, it did not take long for the fruits of theirschemes to manifest. Bribery and corruption soon became the order of the day, especially for natives at their employ: the men of Umuofiawere made to pay two hundred and fifty bags of cowries, instead of two hundred bags, to appease the white man so as to release their leaders. "They did not know that fifty bags would go to the court messengers, who had increased the fine for that purpose" (139).Thus, it would not be preposterous if one assumes that deceit and fraud seemed to be the driving forceswhich propelled the white man's system of justice in Umuofia. No wonder, at the middle of his narratives in chapter twenty, Achebe quipped: 'they had built a court where the District Commissioner judged cases in ignorance' (123).

\section{Conclusion}

In the preceding paragraphs, we saw Achebe's use of literary genre to underscore the reality of ethics, law and justice in pre-colonial Igbo communities. We saw that the communities had judicial systems which, even though chided by the Europeans, were nonetheless effective in the smooth ordering of their societies. Justice was always for the victim and not for the highest bidder. And we did see that with the advent of the white man's religion and culture, people began to lose the sense of awe attendant to sacred things; the abiding ethical values of truth and honesty began to wane; and the scandalous crimes of deceit and corruption which still perdure till this day, started to take their roots.

It was not as if Umuofia and surrounding environs were a blissful haven devoid of conflicts and crimes. At the time of Achebe's setting, people were still killing twins; those afflicted with sicknesses that engorged their bodies were cast to evil forests to die; and clans frequently went to wars (that could have been easy averted) with neighbouring communities over trivial issues. Thanks to the coming of the white men, these issues were greatly resolved. But the point being made here is that the native people's system of checks and balance was no respecter of personalities, as against the western system which the rich and powerful couldeasily circumvent.In Achebe's Umuofia, everyone was treated equally before the law, and anyone who tried to subvert the law and traditions of the land incurred the wrath of the gods.

In Things Fall Apart, Achebe's principal character - Okonkwo constituted himself into law and, paradoxically, a violator of clan laws and traditions by beating his wife - Ojiugo in the Week of Peace (21); defying the warning from the oracle of the Hills and Caves and partook in the killing of Ikemefuna (40-43); by inadvertently killing Ezudu's sixteen year old son at thelatter's funeral (86); and finally by taking his own life, which was an abomination against the earth goddess (146). In all of these, he received requisite punishments, in spite of being one of the nine egwugwu - spiritual leaders of his clan. Even when his best friend - Obierika sympathized with him, it was never to becloud his reverence for the sanctity of the laws. This was why he participated in the destruction of Okonkwo's house after the latter inadvertently killed Ezudu's son and fled to Mbanta (87); and also whyhe refused to touch the dangling body of Okonkwo when he committed suicide (146-7). The laws and customs of the land were sacrosanct, and blind obedience to their provisions, irrespective of personalities implicated, ironically attunes more to the blind-folded image of lady justice of western cultures than anything else.

This literary masterpiece - Things Fall Apart was a genuine attempt to tell the story of a people, and their experience with the coming of the Europeans. It was a defense against the often thoughtless attack of European and Eurocentric writers who saw nothing good in the pre-colonial Africa. The work used the experience of Umuofia clan of Igbo extraction to reveal that Africans had a rich cultural heritage, with high moral standards codified in laws, and a robust judicial system. Like communities of other climes, their ethical, legal and justice systems were open to evolution. Even though Achebe did not engage himself directly in the polemics of the derivable value of the white man's invasion of Umuofia, his revelations underscored the genesis of bribery and corruption: twin monsters that have eaten deep into the fabrics of our national psyche today.

\section{References}

[1]. Achebe, C. (1958). Things Fall Apart. New Hampshire: Heinemann Ltd.

[2]. Aquinas, T. (1954).Summa Theologica. 1a2ae, 90.4.Trans. by J. G. Dawson. Oxford: Basil Blackwell.

[3]. Aristotle. Nicomachean Ethics. Bk.V, CH.6, $1134 \mathrm{~b}$.

[4]. Bentham, J. (1789).An Introduction to the Principles of Morals and Legislation. Oxford: Clarendon Press.

[5]. Campbell, T. D. "The Contribution of Legal Studies", in R. E. Goodin and P. Pettit (Eds.). (1995). A Companion to Contemporary Political Philosophy.NJ.: Wiley-Blackwell.

[6]. Definition of law in Oxford Dictionaries. Retrieved on 08/09/2014 from: http://www.oxforddictionaries.com/definition/english/law

[7]. Dworkin, R. (1986). Law's Empire. Cambridge, MA: Harvard University Press.

[8]. 'Ethics', in Definitions of Anthropological Terms. Retrieved on 11/09/2014 from: http:/oregonstate.edu/instruct/anth370/gloss.html

[9]. "Ethics" in Dictionary.com. Retrieved on 11/09/2014 from: http://dictionary.reference.com/browse/ethic

[10]. Hobbes, T. (2010 [1651]).Leviathan. (Eds.). A.P. Martinich and B. Battiste. Peterborough, ON: Broadview Press.

[11]. McCoubrey, H. and White, N. D. (1996).Textbook on Jurisprudence.(Second Edition). London: Blackstone Press Limited.

[12]. Ogbujah, C. N. (2011.). Philosophy: A Thematic Introduction. (Second Edition). Port Harcourt: Geocelia. 
[13]. Ogbujah, C. (2014). 'African Cultural Values and Inter-communal Relations: The Case with Nigeria',in Developing Country Studies, Vol 4, No 24, 208-217, ISSN 2225-0565.

[14]. Plato. (1955). The Republic. Trans. by D. Lee. London: Penguin Classics.

[15]. Plato. (1970). The Laws. Trans. by T. J. Saunders. London: Penguin Classics.

[16]. Rawls, J. (Revised edition, 1999). A Theory of Justice. Oxford: Oxford University Press.

[17]. Raz, J. (2009). The Authority of Law. Oxford: Oxford University Press.

[18]. Rousseau, J. (1762). The Social Contract. Trans. by G. D. H. Cole. Book II: Chapter 6 (Law). Assessed on 18/10/2014 from: http://www.marxists.org/reference/subject/economics/rousseau/social-contract/ch02.htm\#006

[19]. Tylor, E. B. (1920 [1871]).Primitive Culture. New York: J. P. Putnam's Sons. 